\title{
In vivo reflectance confocal microscopy in a typical case of melasma
}

\author{
Microscopia confocal reflectante in vivo em um caso típico de melasma
}

\author{
Mariana Carvalho Costa ${ }^{1}$ \\ Leonardo Spagnol Abraham ${ }^{3}$ \\ Marco Ardigo 5
}

\author{
Hernando Vega Eljaiek ${ }^{2}$ \\ Luna Azulay-Abulafia ${ }^{4}$
}

\begin{abstract}
Melasma is a common disorder of hypermelanosis that affects mainly young and middle-aged women of Fitzpatrick's phototypes III-V. The disease significantly impacts their lives. In vivo reflectance confocal microscopy, a spreading technology for the noninvasive evaluation of the skin up to the papillary dermis, provides real-time en face images with cellular resolution. We present a case of melasma with in vivo reflectance confocal microscopy findings closely correlated to the histopathological features described in the literature.

Keywords: Hyperpigmentation; Microscopy, confocal; Pigmentation disorders

Resumo: O melasma é um distúrbio pigmentar caracterizado por hipermelanose, que afeta principalmente mulheres jovens e de meia-idade com fototipos III-V de Fitzpatrick e acarreta em impacto significativo na qualidade de vida das mesmas. A microscopia confocal reflectante in vivo, uma tecnologia em expansão voltada para análise da pele até a derme superior, proporciona imagens en face em tempo real com resolução celular. Apresentamos um caso de melasma com achados na microscopia confocal reflectante in vivo fortemente correlacionados com as características histopatológicas descritas na literatura. Palavras-chave: Hiperpigmentação; Microscopia confocal; Transtornos da pigmentação
\end{abstract}

Despite being a common disorder of hypermelanosis, the exact etiology of melasma remains unknown and its treatment represents a challenge for dermatologists. Hormonal disturbances and sunlight seem to be implicated in causing or aggravating the hyperchromic macules; however, other pathogenic factors have been recently reported such as stem cell factors, c-Kit, neural and growth factors. ${ }^{1}$ Most

\footnotetext{
Received on 23.12.2011.

Approved by the Advisory Board and accepted for publication on 23.01.2012.

* Work conducted at Instituto de Dermatologia e Estética do Rio de Janeiro (IDERJ) - Rio de Janeiro (RJ), Brazil. Conflict of interest: None

Financial funding: The RCM device was gently borrowed by Lucid Technologies, Henrietta, New York, NY, USA (from November to December 2012)

MD - Instituto de Dermatologia Professor Rubem David Azulay (Professor Rubem David Azulay Institute of Dermatology) - Santa Casa da Misericórdia do Rio de Janeiro - Rio de Janeiro (RJ), Brazil.

MD - Instituto de Dermatologia Professor Rubem David Azulay - Santa Casa da Misericórdia do Rio de Janeiro. Instituto de Anatomia Patológica Professor João Lobato (Professor João Lobato Institute of Anatomical Pathology) - Santa Casa da Misericórdia do Rio de Janeiro - Rio de Janeiro (RJ), Brazil.

MD - Department of Pathology - Federal University of Rio de Janeiro (UFRJ). Instituto de Dermatologia Professor Rubem David Azulay - Santa Casa da Misericórdia do Rio de Janeiro. Instituto de Dermatologia e Estética do Rio de Janeiro - IDERJ (Institute of Aesthetics and Dermatology of Rio de Janeiro) Rio de Janeiro (RJ), Brasil.

PhD - Department of Dermatology - State University of Rio de Janeiro (UERJ). Instituto de Dermatologia Prof. Rubem David Azulay - Santa Casa da Misericórdia do Rio de Janeiro. Instituto de Dermatologia e Estética do Rio de Janeiro (IDERJ) - Rio de Janeiro (RJ), Brasil.

MD - Department of Clinical Dermatology / Confocal Microscopy - San Gallicano Dermatological Institute - Rome, Italy.

(C)2012 by Anais Brasileiros de Dermatologia
} 
patients are women between 20 to 50 years old, of Fitzpatrick's phototypes III-V - mainly Oriental, Hispanic, Arab and North American. The disease often significantly impacts their lives as lesions occur predominantly in the face. ${ }^{1,2}$

The histopathological classification of melasma, by identifying the location and extension of melanin pigmentation in the lesion, would probably lead to better patient management and aid treatment choice. Two patterns of melasma were observed in one study - epidermal and dermal patterns. ${ }^{3}$ The former showed melanin deposits in the basal and suprabasal layers and melanocytes that were highly dendritic and full of pigment. The latter showed superficial and deep perivascular melanophages in the dermis. However, histopathological analysis is not essential for diagnosis. In fact, due to its invasiveness and risk of scars, it is not well accepted by the patients. With regard to other assessment tools, Wood's light examination to determine the four types of melasma is not a precise method. ${ }^{4}$

In vivo reflectance confocal microscopy (RCM) is an upcoming technology for the noninvasive evaluation of the skin up to the papillary dermis. ${ }^{5}$ This technique provides real-time en face images with a resolution close to that of histopathological examination. Since melanin is one of the main targets of $\mathrm{RCM}$, this technique appears to be an interesting method of evaluation to detect pigment disorders such as melasma. ${ }^{6,7,8}$

We report a case of extensive melasma in which RCM findings were closely correlated with the histopathological findings previously described in the literature. A 47-year-old female, Fitzpatrick's phototype IV, presented a 4-year history of hyperchromic macules in many regions of the face with no previous treatment (Figure 1). She reported no relation to

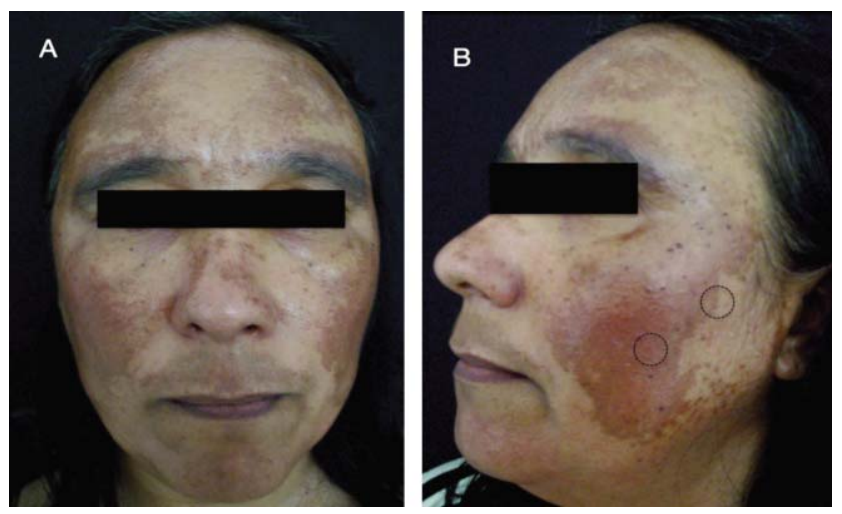

Figure 1: A and B. Clinical images of a case of severe melasma, with extensive lesions in the frontal and malar regions pregnancy or use of birth control pills, but intense sunlight exposure since childhood. Dermoscopy revealed irregular pigmentation and blood capillary vessels in some parts of the lesions. RCM examination (Vivascope $1500^{\circledR}$ device - Lucid Technologies, Henrietta, New York, NY, USA) showed the presence of multiple activated melanocytes (bright dendritic cells) in the upper layers of the epidermis, and melanophages (bright irregularly-shaped bodies among bundles of collagen) in the upper dermis (Figures 2, 3 and 4).

Based on the present case and on previous reports, we consider RCM to be a useful tool to define pigment presence and location in melasma.
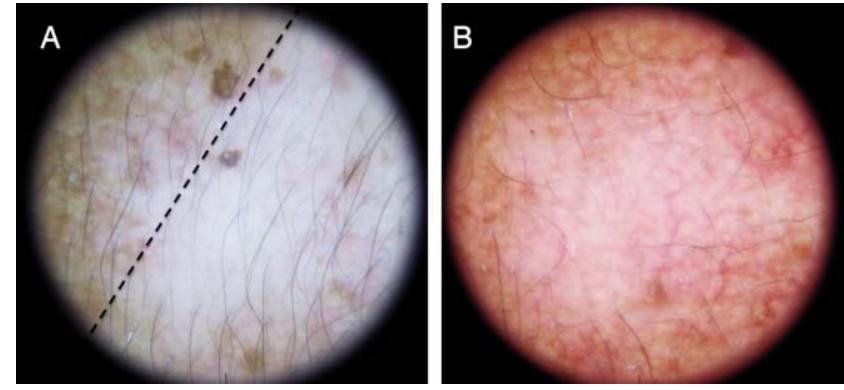

FiguRE 2: Dermoscopic images of the lesions reveal irregular pigmented areas (A) and capillary vessels in some parts (B)

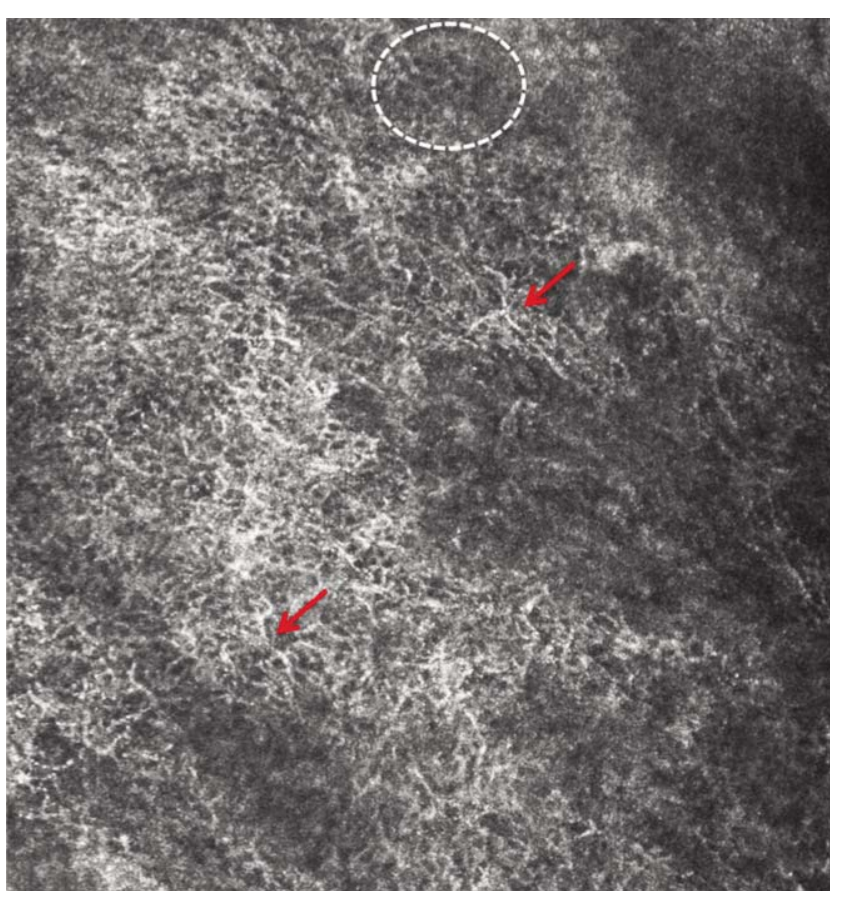

FIGURE 3: RCM image shows bright dendritic cells in the upper layers of the epidermis, corresponding to activated melanocytes (red arrows). Detail of the "honeycomb pattern" in a small normal skin area at the level of the spinous layer (white circle) 


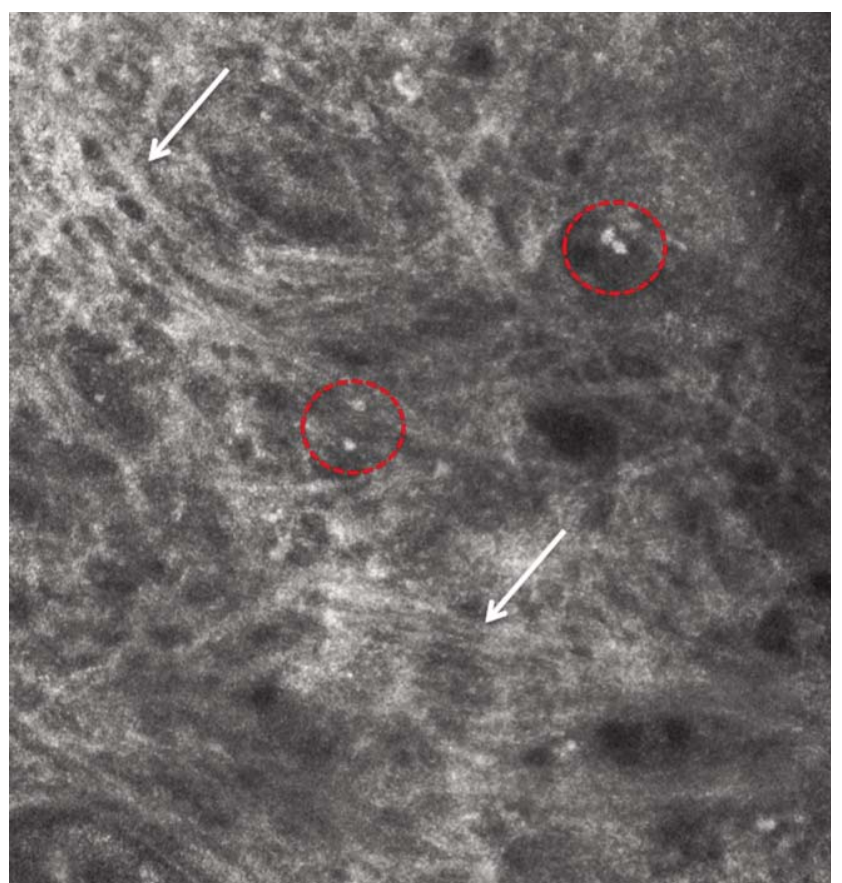

Figure 4: RCM image shows bright irregularly-shaped bodies, corresponding to melanophages (red circles), among bright elongated structures representing bundles of collagen (white arrows) in the upper dermis
Consequently, this technique improves patient management and aids treatment choice. Moreover, we believe that this technology will probably be useful in therapy response evaluation (follow-up).

\section{REFERENCES}

1. Sheth VM, Pandya AG. Melasma: a comprehensive update: part II. J Am Acad Dermatol. 2011;65:689-714.

2. Berardesca E, Ardigo M, Berardesca M, Cameli N. Melasma: current and future treatments. Expert Dermatol. 2008;3:187-93.

3. Sanchez NP, Pathak MA, Sato S, Fitzpatrick TB, Sanchez JL, Mihm MC Jr. Melasma: a clinical, light microscopic, ultrastructural, and immunofluorescence study. J Am Acad Dermatol. 1981;4:698-709.

4. Liu H, Lin Y, Nie X, Chen S, Chen X, Shi B, et al. Histological Classification of melasma with reflectance confocal microscopy: a pilot study in Chinese patients. Skin Res Tech. 2011;17:398-403.

5. Rito C, Pineiro-Maceira J. Microscopia confocal reflectante aplicada ao diagnóstico do melanoma cutâneo. An Bras Dermatol 2010;84:636-42.

6. Ardigo M, Cameli N, Berardesca E, Gonzalez S. Characterization and evaluation of pigment distribuition and response to therapy in melasma using in vivo reflectance confocal microscopy: a preliminary study. J Eur Acad Dermatol. 2010;24:1296303.
7. Kang HY, Bahadoran P, Ortonne JP. Reflectance confocal microscopy for pigmentary disorders. Exp Dermatol. 2010;19:233-9.

8. Kang HY, Bahadoran P, Suzuki I, Zugaj D, Khemis A, Passeron T, et al. In vivo reflectance confocal microscopy detects pigmentary changes in melasma at a cellular level resolution. Exp Dermatol. 2010;19:e228-33.

\footnotetext{
MAILING ADDRESS / ENDEREÇO PARA CORRESPONDÊNCIA: Mariana Carvalbo Costa Avenida Alexandre Ferreira, 206 - Lagoa 22470-220 Rio de Janeiro, RJ. E-mail: maricosta133@gmail.com
}

How to cite this article: Costa MC, Eljaiek HV, Abraham LS, Azulay-Abulafia L, Ardigo M. In vivo reflectance confocal microscopy in a typical case of melasma. An Bras Dermatol. 2012;87(5):782-4. 